\title{
Digital Classroom untuk Meningkatkan Kemampuan Metakognisi Mahasiswa dalam Pembelajaran Pkn
}

\author{
Abdul Latif1, Ahmad Al Yakin², Herlina Ahmad3 \\ 1 Pendidikan Pancasila dan Kewarganegaraan, Universitas Terbuka \\ Email: penulis@gmail.com \\ 2 Pendidikan Pancasila dan Kewarganegaraan, Universitas Al Asyariah Mandar \\ 3 Pendidikan Matematika, Universitas Al Asyariah Mandar, email: herlinaahmad39@gmail.com
}

\section{Artikel info}

Artikel history:

Received; 25-08-209

Revised:12-09-2019

Accepted;28-09-2019
Abstrak: Metakognisi berhubungan dengan proses berpikir mahasiswa tentang berpikir mereka sendiri dan kemampuan mereka menggunakan strategi-strategi belajar tertentu dengan tepat dalam rangka membangun strategi untuk memahami dan memecahkan masalah. Proses metakognisi yaitu (1) perencanaan, (2) pengecekan sendiri, (3) kesadaran dan (4) strategi kognitif. Untuk meningkatkan kemampuan metakognisi mahasiswa diperlukan strategi yang dapat menjembatani peningkatan tersebut. Digital classroom sangat tepat digunakan dalam abad 21 sebab mampu mengintegrasikan ICT dalam proses pembelajaran. Digital classroom yang dimaksud dalam penelitian ini yaitu aplikasi yang dibuat oleh google bertujuan untuk membantu dosen dan mahasiswa mengorganisasi kelas serta berkomunikasi dengan mahasiswa tanpa harus terikat dengan jadwal kuliah di kelas, selain itu aplikasi ini membantu para dosen menyusun dan mengumpulkan tugas dari mahasiswa serta menilai tugas tersebut. Penelitian ini adalah penelitian pengembangan dengan model pengembangan Plomp dengan lima tahapan yaitu (1) tahap pengkajian awal (Preliminary Investigation Phase), (2) tahap perancangan (design phase), (3) tahap realisasi/konstruksi (realization/construction phase), (4) tahap tes, evaluasi dan revisi (test, evaluation and revision phase), serta (5) tahap implementasi (implementation phase). Berdasarkan hasil analisis diperoleh pengembangan pembelajaran PKn melalui digital classroom dalam meningkatkan kemampuan metakognitisi mahasiswa berada pada kategori yang valid, praktis, dan efektif.

Abstract: Metacognition relates to students' thinking processes
about their own thinking and their ability to use certain learning
strategies appropriately in order to develop strategies for
understanding and solving problems. Metacognition processes
are (1) planning, (2) self-checking, (3) awareness and (4)
cognitive strategies. To improve students' metacognition skills,
strategies are needed to bridge the improvement. Digital 
classroom is very appropriate to be used in the 21st century because it is able to integrate ICT in the learning process. Digital classroom referred to in this research is an application made by Google that aims to help lecturers and students organize classes and communicate with students without having to be tied to class schedules in class, besides this application helps lecturers arrange and collect assignments from students and assess assignments the. This research is a development study with a Plomp development model with five stages namely (1) the preliminary investigation phase (Preliminary Investigation Phase), (2) the design phase, (3) the realization / construction phase, (realization / construction phase), (4) the test, evaluation and revision phase (test, evaluation and revision phase), and (5) the implementation phase. Based on the results of the analysis obtained by the development of Civics learning through digital classroom in improving students' metacognitive abilities are in a valid, practical, and effective category.

Keywords:

Digital Classroom;

Model Plomp;

Kemampuan

Metakognisi;

PKn.

\section{Pendahuluan}

Pesatnya perkembangan teknologi dan internet dalam beberapa tahun terakhir memengaruhi dunia pendidikan terutama dalam proses pembelajaran. Pendidikan berkembang karena dampak dari Internet. Ini terlihat dari cara mengajar yang tidak dapat mengajar mahasiswa dengan cara yang sama di mana dosen dulunya diajarkan. Kondisi pembelajaran saat ini harus mampu mengintegrasikan teknologi ke dalam proses pembelajaran, salah satu perkembangan teknologi yang dirasakan dalam dunia pendidikan adalah penerapan digital classroom. Digital classroom sangat tepat digunakan dalam abad 21 sebab mampu mengintegrasikan ICT dalam pengajaran dan pembelajaran. Digital classroom yang dimaksud dalam penelitian ini adalah penggunaan aplikasi Google Classroom. Google classroom adalah aplikasi yang dibuat oleh googleyang dirilis resmi pada Agustus 2014. Sesuai dengan namanya, google classroom mencoba "memindahkan" ruang kelas ke ranah online. Jadi dosen masih bisa bertemudengan mahasiswa, hanya saja kini melakukannya melalui layar gadget masing-masing. Google classroombertujuan untuk membantu dosen dan mahasiswa mengorganisasi kelas serta berkomunikasi dengan mahasiswa tanpa harus terikat dengan jadwal kuliah di kelas. Disamping itu dosen dapat memberikan tugas dan langsung memberikan nilai kepada mahasiswa.

Penelitian terkait tentang persepsi guru terhadap digital natives, sumber belajar digital dan motivasi memanfaatkan sumber belajar digital sebelumnya yang dilakukan oleh Dopo. F.B dan Ismaniati. C (2015) [1] menghasilkan (1) Ada pengaruh yang positif dan signifikan persepsi guru tentang digital natives terhadap motivasi guru memanfaatkan sumber belajar digital. (2) Ada pengaruh yang positif dan signifikan persepsi guru tentang sumber belajar digital terhadap motivasi guru memanfaatkan sumber belajar digital. (3) Ada pengaruh yang positif dan signifikan, persepsi guru tentang digital natives dan persepsi guru tentang sumber belajar digital secara bersama-sama terhadap motivasi guru memanfaatkan sumber belajar digital.

Metakognisi berhubungan dengan proses berpikir mahasiswa tentang berpikir mereka sendiri dan kemampuan mereka menggunakan strategi-strategi belajar tertentu dengan tepat dalam rangka membangun strategi untuk memahami dan memecahkan masalah. Proses metakognisi yaitu (1) perencanaan, (2) pengecekan sendiri, (3) kesadaran dan (4) strategi 
kognitif. Arsyad (2016) [2] mengatakan bahwa kemampuan metakognisi adalah pengetahuan dan keterampilan seseorang dalam rangka membangun strategi kognitif dan menyadari penggunaannya dalam memahami materi dan memecahkan masalah, sedangakan model pembelajaran menumbuhkembangkan kemampuan metakognisi itu sendiri adalah suatu model pembelajaran yang selain untuk mengajarkan materi bahan ajar PKn, juga sekaligus meningkatkan kemampuan kognitif mahasiswa untuk menguasai bahan ajar PKn. meningkatkan kemampuan kognitif yang dimaksud adalah proses pengembangan kemampuan metakognisimahasiswa melalui pendekatan pelatihan (training approach) yang tergabung (embedded) dan tergantung (dependent) pada materi bahan ajar yang disajikan dalam google classrom

Untuk mendukung teoritis diatas tentang konsep metakognitis,O'Neil \& Brown (1997) [3] telah melakukan penelitian tentang "perbedaan pengaruh format pertanyaan dalam penilaian matematika terhadap metakognisi dan sikap" dengan sampel sebanyak 1.032 responden dan 12 sekolah dalam 59 kelas pada delapan sekolah menengah pertama di California. Aspek metakognitif yang menjadi fokus penelitian mereka ada dua macam, yaitu strategi kognitif dan pengecekan diri. Adapun hasil penelitian mereka yang berkaitan aspek kognitif adalah: (a) terdapat pengaruh yang signifikan jenis kelamin terhadapa penggunaan strategi kognitif dalam menjawab pertanyaan-pertanyaan terbuka dan pilihan ganda $(\rho<$ $0,001)$, dengan perempuan lebih banyak menggunakan strategi kognitif $(M=2,73, S D=0,58)$ daripada laki-laki $(M=2,59, S D=0,58)$; (b) terdapat pengaruh yang dignifikan format pertanyaan terhadap penggunaan strategi kognitif $(\rho<0,001)$, pada pernyataan terbuka siswa lebih banyak menggunakan strategi kognitif $(M=2,70, S D=0,56)$ daripada pertanyaan pilihan ganda $(M=2,61, S D=0,61)$; (c) terdapat pengaruh interaksi jenis kelamin dan format pertanyaan terhadap penggunaan strategi kognitif $(\rho<0,001)$, dengan perempuan lebih banyak menggunakan strategi kognitif daripada laki-laki dalam dua kondisi (pertanyaan terbuka dan pilihan ganda) dan kedua kelompok (laki-laki dan perempuan) lebih banyak menggunakan strategi kognitif pada pertanyaan terbuka daripada pertanyaan pilihan ganda.

Berdasarkan penelitian tersebut, maka dapat dijadikan referensi dalam pengembangkan model pembelajaran PKn dalam meningkatkan kemampuan metakognitisi mahasiswa melalui digital classroom. Berdasarkan latar belakang di atas, maka rumusan penelitian ini adalah "bagaimanakah pengembangan pembelajaran PKn dalam meningkatkan kemampuan metakognitisi mahasiswa melalui digital classroom". Tujuan penelitian ini yaitu menghasilkan pengembangan pembelajaran PKn dalam meningkatkan kemampuan metakognitisi mahasiswa melalui digital classroom yang berkualitas dengan kriteria valid, praktis dan efektif.

\section{Metakognisi}

Pengertian metakognisi yang dikemukakan oleh para pakar umumnya memberika penekanan pada proses berpikir seseorang. Pengertian yang paling umum dari metakognisi adalah thinking about thinking (berpikir tentang berpikir) atau learn how to learn (belajar bagaimana belajar). O'neil \& Brown [3] mengemukakan pengertian metakognisi sebagai proses seseorang berpikir tentang berpikir mereka sendiri dalam rangka membangun strategi untuk memecahkan masalah. Sejalan dengan pengertian tersebut, metakognisi berhubungan dengan berpikir mahasiswa tentang berpikir mereka sendiri dan kemampuan mereka mengunakan strategi-strategi belajar tertentu dengan tepat. Misalnya, seseorang dengan tipe belajar visual menyadari bahwa membuat suatu peta konsep merupakan cara terbaik baginya untuk memahami dan mengingat sejumlah besar informasi baru.

Aspek-aspek pribadi mahasiswa, yang berkaitan erat dengan metakognisi mahasiswa, yakni fungsi kognisi yang mencakup (1) taraf intelegensi; (2) daya kreativitas; (3) bakat khusus; (4) organisasi kognitif; (5) taraf kemampuan berbahasa; (6) daya fantasi; (7) gaya belajar (gaya kognitif, tipe belajar dan gaya berpikir); dan (8) teknik-teknik studi.Anderson \& Krathwohl (2001) [4] merevisi Taksonomi Bloom tentang aspek kognitif menjadi dua dimensi, yaitu: (1) 
dimensi proses kognitif dan (2) dimensi pengetahuan. Hasil revisi yang menonjol tentang dimensi proses kognitif adalah ditiadakannya aspek sintesis diantara aspek analisis dan aspek evaluasi serta ditambahkannya aspek mencipta/kreasi (create) sesudah aspek evaluasi.

Sedangkan untuk aspek-aspek dari dimensi pengetahuan yang dikemukakan adalah: (1) pengetahuan faktual (factual knowledge), (2) pengetahuan konseptual (conceptual knowledge), (3) pengetahuan prosedural (procedural knowledge), dan (4) pengetahuan metakognitif (metacognitive knowledge). Baker dan Brown (dalam Arsyad:2016) [2] mengemukakan bahwa metakognisi memiliki dua komponen, yaitu: (a) pengetahuan tentang kognisi, dan (b) mekanisme pengendalian diri. Tiga aspek dari pengetahuan metakognitif yaitu: (a) pengetahuan strategis (strategic knowledge), (b) pengetahuan tentag tugas kognitif, termasuk pengetahuan kontekstual dan kondisional, dan (c) pengetahuan-diri (self knowledge). Sejalan dengan hal di atas, Flavell membagi pengetahuan metakognitif berdasarkan tiga variabel, yaitu: (a) variabel pengetahuan-diri, (b) variabel tugas, dan (c) variabel strategis. Tiga cara untuk menjelaskan metakognisi dalam pembelajaran matematika, yaitu: (a) keyakinan dan intuisi, (b) pengetahuan dan (c) kesadaran-diri (regulasi-diri).

Arsyad (2016) [2] mengatakan bahwa kemampuan metakognitif adalah pengetahuan dan keterampilan seseorang dalam rangka membangun strategi kognitif dan menyadari penggunaannya dalam memahami materi dan memecahkan masalah, sedangakan model pembelajaran dalam meningkatkan kemampuan metakognisi itu sendiri adalah suatu model pembelajaran yang selain untuk mengajarkan materi bahan ajar PKn, juga sekaligus meningkatkan kemampuan kognitif mahasiswa untuk menguasai bahan ajar PKn. meningkatkankemampuan kognitif yang dimaksud adalah proses pengembangan kemampuan metakognisimasiswa melalui pendekatan pelatihan (training approach) yang tergabung (embedded) dan tergantung (dependent) pada materi bahan ajar yang disusun ke dalam google classroom.

Pengetahuan tentang metakognisi terdiri dari informasi dan pemahaman yang dimiliki seorang mahasiswa tentang proses berpikirnya sendiri. Mahasiswa perlu mengembangkan pengetahuan kondisional untuk strategi-strategi kognitif umum atau dengan kata lain mereka perlu mengembangkan pengetahuan tentang kapan dan mengapa menggunakan strategi secara tepat. Pengetahuan kondusional merujuk pada pengetahuan terhadap situasi dimana mahasiswa dapat menggunakan pengetahuan metakognitif. Flavel mengemukakan bahwa pengetahuan diri merupakan komponen penting dalam metakognisi. Dalam model pengetahuan diri, Flavel memasukkan pengetahuan tentang kekuatan dan kelemahan seseorang mengenai kognitif dan belajar. Misal mahasiswa yang tahu bahwa mereka secara umum mengerjakan lebih mudah tes pilihan berganda dari pada tes essai memiliki pengetahuan diri tentang keterampilan menghadapi tes.

Salah satu komponen kognitif yang sangat erat kaitannya dengan usaha dan aktivitas mahasiswa dalam menangkap dan memahami materi yang diajarkan adalah strategi belajar (strategi kognitif). Gagne menggolongkan strategi kognitif sebagai hasil belaajr, sehingga perlu diajarkan dan dilatihkan kepada mahasiswa. Teori-teori belajar yang mendukung starategi belajar kognitif adalah (1) teori konstruktivisme, (2) belajar kognitif oleh De Block, (3) belajar berpikir dan belajar untuk belaajr oleh Parreren, (4) belajar pengaturan koginitif oleh Gagne.

\section{Indikator Pembangun Metakognisi}

Flavell mengemukakan bahwa metakognisi meliputi dua komponen, yaitu (a) pengetahuan metakognitif (metacognitive knowledge) dan (b) pengalaman atau regulasi metakognitif (metacognitive experinces or regulation). Pendapat serupa dikemukakan oleh Baker \& Brown dan Gagne bahwa metakognisi memiliki dua komponen yaitu (a) pengetahuan tentang kognisi dan (b) mekanisme pengendalian diri dan monitoring kognitif.

Indikator-indikator metakognisi menurut Hacker tergambar dari pengertian metakognisi yang dikemukakannya dalam artikel berjudul "Metacognition:defenitions and empirical foundations" bahwa metakognisi adalah prose berpikir seseorang tentang berpikirnya sendiri. Wujud dari berpikir dalam pengertian ini adalah apa yang seseorang ketahui 
(pengetahuan metakognitif), apa yang dilakukan seseorang (keterampilan metakognitif), dan bagaimana keadaan kognitif dan afektif seseorang (pengalaman metakognitif).

Metakognitif mencakup kemampuan seseorang dalam bertanya dan menjawab beberapa tipe pertanyaan berkaitan dengna tugas yang dihadapi. Pertanyaan-pertanyaan tersebut adalah sebagai berikut:

(a) Apa yang saya ketahui tentang materi, topik atau masalah ini?

(b) Tahukah saya apa yang dibutuhkan untuk mengetahuinya?

(c) Tahukah saya dari mana dapat memperoleh informasi atau pengetahuan?

(d) Berapa lama waktu yang dibutuhkan untuk mepelajarinya?

(e) Strategi-strategi atau taktik-taktik apa yang dapat digunakan untuk mepelajarinya?

(f) Dapatkah saya pahami dengan mendengar, membaca atau melihat?

(g) Akankah saya tahu jika mempelajarinya secara tepat?

(h) Bagaimana saya dapat membuat sedikit kesalahan jika saya membuat sesuatu?

Secara operasional tentang kemampuan metakognitif yang dapat diajarkan kepada mahasiswa, kemampuan untuk menilai pemahaman mereka sendiri, menghitung berapa waktu yang mereka butuhkan untuk emmpelajari sesuatu, memilih rencana yang efektif untuk belajar atau memecahkan masalah, bagaimana cara mereka memahami ketika tidak memahami sesuatu dan bagaimana cara memperbaiki diri sendiri, kemampuan untuk meprediksi apa yang cenderung akan terjadi atau mengatakan mana yang dapat diterima oleh akal dan mana yang tidak.

\section{Starategi Meningkatkan Kemampuan Metakognisi}

Kemampuan metakognisi sebagai salah satu hasil belajar tertentu dapat ditingkatkan melalui pengajaran atau pelatihan. Jenis dan strategi pelatihan metakognisi bisa bermacammacam tergantung dari kriteria pengklasifikasiannya. Berikut ini adalah pengklasifikasian strategi pelatihan metakognisi yang digunakan oleh Osman dan Hannafin dan dijelaskan kembali oleh Huitt [5] bahwa: "As criteria for their classification of metakognitive training strategis Osman and Hannafin used "training approuch" and "releationship to lesson content." They describe metacognitive taraining strategies taht may be embedded, or integrated within acriterion lesson and strategies which may be taught separately-deteched-from academic subjects. With respect to the role of lesson content. Content-dependent strategies focusexplicitly on concepts that promote learning of aparticular content. Conversely, content-independent strategies are content-free, general strategies not specific to particular academic subjects."

Dalam kutipan di atas, Huitt menjelaskan bahwa Osman dan Hannafin menggunakan dua kriteria untuk mengklasifikasikan strategi-strategi pelatihan metakognisi, yakni: pendekatan pelatihan (training approuch) dan hubunannya dengan materi pelajaran (relationship to lesson content). Osman dan Hannafinmenggambarkan strategi-strategi pelatihan metakognisi berdasarkan pendekatannya, ada yang melekat (embedded) atau tergabung dalam isi pelajaran dan ada yang diajarkan secara terpisah (detached) dari amteri pelajaran. Berdasarkan hubungannya dengan konten/materi kuliah, strategi bisa tergantung pada (dependent on) konten/isi materi kuliah.

Mengenai strategi dosen untuk meningkatkan kemampuan metakognisi mahasiswa, mengemuakakn beberapa contoh sebagai berikut.

a. Mintalah mahasiswa untuk memonitor belajar dari berpikir mereka sendiri.

b. Mintalah mahasiswa mempelajari strategi-strategi belajar, seperti SQ3R dan SQ4R.

c. Mintalah mahasiswa membuat prediksi tentang informasi yang akan dipresentasikan berdasarkan apa yang telah mereka baca.

d. Mintalah mahasiswa menghubungkan ide-ide untuk membentuk struktur pengetahuan.

e. Mintalah mahasiswa membuat pertanyaan, bertanya pada diri mereka sendiri tentang apa yang terjadi di sekeliling mereka.

f. Bantulah mahasiswa untuk mengetahui kapan bertanya untuk membantu.

g. Tunjukkan mahasiswa bagaimana mentransfer pengetahuan, sikap, nilai dan keterampilan pada situasi atau tugas lain 
Salah satu aspek yang erat kaitannya dengan pengembangan model pembelajaran untuk meningkatkan kemmapuan metakognisi adalah penialain (assesment). Penialain dapat dialkukan sebagai petunjuk awal untuk melakukan pengemabngan kemampuan metakognisi atau dalam rangka mengukur perkembangan metakognisi itu sendiri. Bahkan yang lebih penting lagi, penialain kemampuan metakognisi dilakukan dalam kedudukannya sebagai aspek pengetahuan atau tujuan pembelaajran.

Sangat sulit untuk menilai pengetahuan dan keterampilan metakognisi menggunakan pegukuran sederhana secara tertulis (paper-and-pencil measures). Agar tujuan-tujuan yang berkaitan pengetahuan metakognisi sebaiknya diukur/dinilai dalam konteks aktivitasdalam kelas dan menggabungkan strategi-strategi yang bervariasi.

Tes kinerja (performance test)menjadi salah satu alat penialian yang cocok untuk meniali kemampuan metakognisi mahasiswa. Namun untuk mengoptimalkan proses penilaian kinerja tersebut dosen tetap memerlukan alat pengumpul data (instrumen) pendukung seperti: pedoman observasi, jurnal berpikir mahasiswa, lembar kerja mahasiswa, rubrik mahasiswa, atau bahkan pedoman wawancara.

\section{Digital Classroom}

Darojat, 0. (2018)[7] Menyatakan bahwa faktor penting dalam keberhasilan integrasi teknologi ke pendidikan meliputi: (1) The integration of academic and curricular planning with faculty development; (2) High-quality, ongoing and sustainable faculty development (e.g., in technology, pedagogy and instructional design that supports learning) and access to appropriate tools and resources; (3) Faculty involvement that gives faculty reasonable ownership of choices, designs, and the work environment; (4) Demonstration of institutional commitment to the support of faculty (e.g., in flexible and scalable systems) who are taking difficult steps to engage technology and embrace innovation and change, including fair and progressive reward and incentive systems and adequate available time for learning, experimentation, reflection, and re-learning; (5) Visionary transformational leadership shown by the administration; (6) While the delivery modes of instruction seem to have evolved to include more advanced technologies, the primary purpose of higher education remains the need to deliver quality instruction for learners; (7) Indonesian researchers found that the innovation of online learning in developing countries, such as Indonesia, has proved a daunting task (Literacy \& Access points); (8) Koonts, Li, and Compora (2006) suggested that "careful planning and a systematic design approach...[are] essential to make sure that the needs of the students are continuously being met in an ever-changing environment" ( $p .32)$

Menggunakan goggle classroom secara langsung dapat memberikan manfaat besar untuk dosen dan mahasiswa. Seperti contoh, ketika tugas berbentuk pilihan ganda, dosen tidak perlu lagi mengoreksi satu persatu di lembaran kertas, dengan google classroom nilai akan otomatis keluar saat itu juga. Selain itu juga membantu menganalisa pembahasan mana yang belum dipahami oleh mayoritas mahasiswa, sehingga pelajaran yang mayoritas belum dipahami tersebut dapat diulangi dengan cara yang lebih baik. Sementara manfaat untuk mahasiswa yaitu para mahasiswa tetap dapat mengikuti kelas meski mahasiswa tersebut berhalangan hadir karena sakit atau tidak memungkinkan datang ke kampus karena alasan tertentu. Tentu saja cara ini memberikan kesempatan luas bagi mahasiswa untuk tetap belajar di mana pun.

Google classroom juga dapat mempertemukan mahasiswa dan dosen dengan para pakar melalui video callgoogle hangout. Contohnya saja ketika dosen mengundang pakar ternama seperti BJ Habibie untuk menjelaskan tentang pesawat kepada mahasiswa. Sang pakar tidak perlu hadir di tempat, cukup bertatap secara online melalui video, pembelajaran tetap berjalan lancer. Keberadaan sistem pembelajaran digitalmenarik dan efektif membantu dosen atau mahasiswa yang tidak memiliki banyak waktu untuk bertemu tatap muka serta memberikan pengalaman berbeda dari biasanya. Mencoba sistem belajar digital bisa menjadi alternative pembelajaran.

Google classroom diesain khusus untuk para dosen/guru dan mahasiswa/siswa, google classroom menyediakan serangkaian perangkat gratis diantaranya (1) Gmail, (2) Drive, dan (3) Docs. Namun, google classroom cuma tersedia bagi pengguna Google Apps for Education. Adanya 
berbagai perangkat tersebut memungkinkan mahasiswa untuk mengerjakan dan mengumpulkan tugas tanpa menggunakan kertas. Nantinya, para dosen dapat membuat folder Drive untuk setiap tugas dan untuk mahasiswa sehingga semuanya lebih teratur serta membuat salinan Google Docs secara otomatis untuk setiap mahasiswa.

Dalam kaitannya dengan pengembangan model pembelajaran tertentu, Plomp menunjukkan suatu model yang bersifat lebih umum dalam merancang pendidikan (terkhusus model pembelajaran). Model pengembangan Plomp terdiri atas 5 tahap dan diuraikan sebagai berikut (Arsyad, 2016) [2]:

a) Tahap pengkajian awal (preliminary investigation phase)

Tahap ini merupakan tahap analisa kebutuhan atau masalah yang mencakup (a) pengkajian teori-teori yang relevan, (b) mengidentifikasikan informasi, (c) analisis informasi, (d) mendefenisikan atau membatasi masalah dan (e) merencanakan kegiatan lanjutan.

b) Tahap perancangan (design phase)

Kegiatan pada tahap ini bertujuan untuk merancang penyelesaian masalah yang telah diidentifikasikan pada tahap pertama. Rancangan yang dibuat meliputi suatu proses yang sistematik dengan mebagi-bagi masalah besar menjadi masalah-masalah kecil dengan rancangan pemecahannya masing-masing., kemudian pada akhirnya semua bentuk solusi dikumpulkan dan dihubung-hubungkan kembali menjadi suatu struktur pemecahan masalah secara lengkap.

c) Tahap realisasi/konstruksi (realization/construction phase)

Pada tahap ini dibuat prototipe yaitu rancangan utama yang berdasarkan pada rancangan awal. Dalam konteks pendidikan tahap kedua dan ketiga di atas disebut tahap produksi

d) Tahap tes, evaluasi dan revisi (test, evaluation, revition phase)

Tahap ini bertujuan mempertimbangkan mutu dari rancangan yang akan dikembangkan. Juga membuat keputusan melalui pertimbangan yang matang. Evaluasi mencakup proses menghimpun, memproses dan menganalisis informasi secara sistematis. Hal ini dilakukan untuk menilai kualitas pemecahan yang dipilih. Selanjutnya direvisi kemudian kembali kepada kegiatan merancang dan seterusnya. Siklus yang terjadi ini merupakan siklus umpan balik dan berhenti setelah memperoleh pemecahan yang diinginkan.

e) Tahap implementasi (implementation phase)

Pada tahap ini pemecahan telah diperoleh setelah melalui proses evaluasi. Pemecahan tersebut dianggap memenuhi masalah yang dihadapi. Karena itu pemecahan yang dipilih dapat diimplementasikan atau diterapkan dalam situasi yang sesungguhnya.

\section{Metode}

Jenis penelitian ini adalah penelitian pengembangan (Research and Development) dengan model pengembangan Plomp dengan lima tahapan yaitu (1) tahap pengkajian awal (Preliminary Investigation Phase). (2) tahap perancangan (design phase). (3) tahap realisasi/konstruksi (realization/construction phase). (4) tahap tes, evaluasi dan revisi (test, evaluation and revision phase) dan (5) tahap implementasi (implementation phase).

Subjek dalam penelitian ini adalah mahasiswa semester 2 yang memprogramkan mata kuliah PKn pada Program Studi PPKn Universitas Al Asyariah Mandar Tahun Akademik 2018/2019 yang berjumlah 54 yang terdiri dari 22 laki-laki dan 32 perempuan.

Instrumen penelitian ini adalah (1) Tes Hasil Belajar; digunakan untuk mengumpulkan data hasil belajar mahasiswa. (2) Lembar observasi dosen; digunakan untuk mengamati pengelolaan pembelajaran. (3) Lembar observasi mahasiswa; digunakan untuk mengamati aktivitas mahasiswa. (4) Angket respon mahasiswa; Angket respon terhadap proses pembelajaran dan penggunaan google classroom.

Data yang dikumpulkan dalam penelitian ini adalah (1) Data Hasil Validasi Ahli; dilakukan penyebaran prototype pengembangan pembelajaran dan perangkat pembelajaran 
yang telah dirancang kepada beberapa ahli (validator). (2) Data Hasil Belajar; diberikaan sebelum dan setelah proses pembelajaran. (3) Data Aktivitas Mahasiswa; menggunakan lembar observasi. (4) Data Pengelolaan Pembelajaran; menggunakan lembar observasi. (5) Data Respon Mahasiswa; menggunakan angket dan diberikan diakhir pembelajaran.

Data kuantitatif berupa tes hasil belajar dianalisis dengan statistik deskriptif, sedangkan data kualitatif diarahkan untuk menjawab "Bagaimana proses dan hasil pengembangan model pembelajaranuntuk meningkatkan kemampuan metakognisi mahasiswa dalam pembelajaran PKn melalui digital clasroom, yaitu memenuhi kriteria kevalidan, kepraktisan dan keefektifan?".

Analisis data kevalidan pengembangan pembelajaran PKn

Hasil dari lembar validasi dua validator/ahli (orang yang dipandang ahli dalam bidang PKn dan pendidikan $P K n$ ), dihitung nilai rata-rata $V$ dari $V_{1}$ (validator pertama ) dan $V_{2}$ (validator kedua). Kriteria yang digunakan adalah: (1) Nilai V untuk setiap aspek pada RPS, THB, google classroom, lembar observasi kemampuan mengelola pembelajaran, lembar observasi aktivitas mahasiswa dalam pembelajaran dan angket respon mahasiswa terhadap perangkat pembelajaran minimal berada dalam kategori "Cukup Valid"; dan (2) Nilai V untuk keseluruhan aspek minimal kategori "Valid". Apabila tidak demikian, maka perlu dilakukan revisi berdasarkan saran para validator atau dengan melihat kembali aspek-aspek yang nilainya kurang. Selanjutnya dilakukan validasi ulang lalu dianalisis kembali. Demikian seterusnya sampai melihat nilai $\mathrm{V}$ minimal berada dalam kategori Valid.

\section{Analisis data kepraktisan pengembangan pembelajaran PKn}

Analisis secara kualitatif terhadap hasil penilaian dari observer yang mengamati kemampuan dosen mengelola pembelajaran. Dari hasil observer setiap pertemuan, ditentukan nilai rata-rata Kegiatan Dosen (KD) pada setiap pertemuan. Kriteria yang digunakan minimal berada dalam kategori "tinggi".

\section{Analisis data keefektifan pengembangan pembelajaran PKn}

Analisis terhadap keefektifan pengembangan pembelajaran mencakup 3 komponen keefektifan: (1) Hasil belajar mahasiswa, kriteria nilai ditetapkan yaitu minimal 70. (2) Data respon mahasiswa, kriteria yang ditetapkan adalah minimal 50\% mahasiswa memberi respon positif terhadap minimal $70 \%$ dari jumlah item pertanyaan/pernyataan yang ada pada setiap aspek, dan (3) Aktivitas mahasiswa, kriteria yang digunakan adalah nilai aktivitas mahasiswa minimal berada dalam kategori "aktif".

\section{Hasil dan Pembahasan}

Setelah menyusun draft pembelajaran PKn dalam meningkatkan kemampuan metakognisi mahasiswa melalui digital classroom dalam hal ini diwujudkan dalam bentuk: (1) Rencana Pembelajaran Semester (RPS), (2) Tes Hasil Belajar, (3) Lembar observasi dosen, (4) Lembar observasi mahasiswa, dan (5) Angket respon mahasiswa dan (6) aplikasi google classroom. selanjutnya dilakukan penilaian (divalidasi) oleh beberapa orang yang dipandang ahli (expert judgment). Yang dimaksud ahli dalam hal ini adalah para validator yang berkompeten untuk melakukan penilaian terhadap desain pembelajaran. Saran dari para validator digunakan sebagai bahan untuk melakukan revisi desain hasil pengembangan yang dilakukan pada tahap perancangan (draft 1) untuk mendapatkan draft 2.

Dari hasil penelitian menunjukkan bahwa (1) Rencana Pembelajaran Semester (RPS), (2) Tes Hasil Belajar, (3) Lembar observasi dosen, (4) Lembar observasi mahasiswa, dan (5) Angket respon mahasiswa dan (6) aplikasi google classroom ditinjau dari indikator-indikatornya berada pada kategori valid dan sangat valid karena setiap aspek untuk setiap jenis desain mencapai rata-rata nilai lebih dari 3, selain itu semua validator memberikan kesimpulan bahwa desain yang telah dikembangkan adalah baik dan dapat digunakan dengan revisi kecil. Dari hasil penelitian hasil validasi dari para ahli pada berada pada kategori "Valid" 3,5 $\leq \overline{\mathrm{X}}<4,5$. Hal 
ini berarti pembelajaran PKn dalam meningkatkan kemampuan metakognisi mahasiswa melalui digital classroom telah layak untuk diujicobakan. Namun demikian, hasil tersebut menurut saran para ahli masih perlu diperbaiki/ditambah. Setelah dilakukan beberapa revisi berdasarkan masukan dari validator dihasilkan desain pembelajaran draft II, kemudian diujicobakan.

\section{Pembahasan}

Hasil ujicoba yang telah dilakukan dapat digunakan untuk melihat sejauhmana baik tidaknya (1) Rencana Pembelajaran Semester (RPS), (2) Tes Hasil Belajar, (3) Lembar observasi dosen, (4) Lembar observasi mahasiswa, dan (5) Angket respon mahasiswa dan (6) aplikasi google classroom yang telah dirancang serta dievaluasi berdasarkan nilai kevalidan, nilai kepraktisan dan nilai keefektifan.

Kendala-kendala dalam penelitian yang akan dikemukakan, yaitu kendala-kendala selama proses desain pembelajaran, menyangkut tentang implementasi desain pembelajaran di kelas dan kesiapan-kesiapan yang diperlukan untuk memperoleh desain pembelajaran. Kelemahan-kelemahan penelitian yang dikemukakan adalah kelemahan-kelemahan akibat keterbatasan penelitian, khususnya kelemahan pada proses uji coba. Selain itu diungkapkan pula alasan munculnya kelemahan-kelemahan dan alternatif solusi yang dapat ditempuh untuk mengurangi atau meminimalkan kelemahan tersebut.

\section{Simpulan Dan Saran}

Berdasarkan hasil analisis diperoleh pengembangan pembelajaran PKn melalui digital classroom dalam meningkatkan kemampuan metakognitisi mahasiswa berada pada kategori yang valid, praktis, dan efektif.

\section{Ucapan Terimakasih}

Ucapan terimakasih sebesar-besarnya diberikan kepada Universitas Terbuka yang telah sepenuhnya mendanai kegiatan ini melalui dipa Universitas Terbuka tahun anggaran 2019.

\section{Refference}

Ahmad, H. 2017. Herlina Ahmad Application of Teaching Model of Developing Metacognitive Ability (DMA) In Teaching Mathematics. In Prosiding SI MaNIs (Seminar Nasional Integrasi Matematika dan Nilai-Nilai Islami) (Vol. 1, No. 1, pp. 403-413).

Arsyad, Nurdin.2016. Model Pembelajaran Menumbuhkembangkan Kemampuan Metakognitif. Makassar: Pustaka Refleksi.

Anderson, O.W. \& Krathwohl, D.R. 2001. A Taxonomy For Learning, Teaching, and Assessing ( A Revision of Bloom's Taxonomy of Educational Objectives). New York: Addision Wesley Longman, Inc.

Dopo, F. B., \& Ismaniati, C. 2015. Persepsi guru tentang digital natives, sumber belajar digital dan motivasi memanfaatkan sumber belajar digital. Jurnal Inovasi Teknologi Pendidikan, 3(1), $13-24$

Darojat, 0. 2018. Pengintegrasian Teknologi Dalam Proses PembelajaranDi Era Revolusi Industri 4.0. disampaikan dalam Konferensi Nasional Inoveasi Pendidikan di Universitas Al Asyariah Mandar pada tanggal 8 September 2018.

Huitt, William G. 1997. Metacognition. Available: http://tip.psychology.org/-meta.html.

O’Neil Jr, H.F. dan Brown, R.S. 1997. Differensial Effects of Question Formats in Math Assesment on Metacognition and Affect. Los Angeles: CRESST-CSE University of California. 